\title{
Early development of non-hodgkin lymphoma following initiation of newer class antiretroviral therapy among HIV-infected patients - implications for immune reconstitution
}

Gregory D Huhn ${ }^{1,2^{*}}$, Sheila Badri ${ }^{1,2}$, Sonia Vibhakar ${ }^{3,4}$, Frank Tverdek ${ }^{2}$, Christopher Crank ${ }^{2}$, Ronald Lubelchek ${ }^{1,2}$, Blake Max ${ }^{3,4}$, David Simon², Beverly Sha ${ }^{2}$, Oluwatoyin Adeyemi ${ }^{1,2}$, Patricia Herrera ${ }^{1,2}$, Allan Tenorio², Harold Kessler ${ }^{2}$, David Barker ${ }^{1,2}$

\begin{abstract}
Background: In the HAART era, the incidence of HIV-associated non-Hodgkin lymphoma (NHL) is decreasing. We describe cases of NHL among patients with multi-class antiretroviral resistance diagnosed rapidly after initiating newer-class antiretrovirals, and examine the immunologic and virologic factors associated with potential IRISmediated NHL.

Methods: During December 2006 to January 2008, eligible HIV-infected patients from two affiliated clinics accessed Expanded Access Program antiretrovirals of raltegravir, etravirine, and/or maraviroc with optimized background. A NHL case was defined as a pathologically-confirmed tissue diagnosis in a patient without prior NHL developing symptoms after starting newer-class antiretrovirals. Mean change in CD4 and $\log _{10} \mathrm{VL}$ in $\mathrm{NHL}$ cases compared to controls was analyzed at week 12, a time point at which values were collected among all cases.

Results: Five cases occurred among 78 patients (mean incidence $=64.1 / 1000$ patient-years). All cases received raltegravir and one received etravirine. Median symptom onset from newer-class antiretroviral initiation was 5 weeks. At baseline, the median CD4 and VL for NHL cases $(n=5)$ versus controls ( $n=73)$ were 44 vs.117 cells/ mm3 ( $p=0.09)$ and 5.2 vs. $4.2 \log _{10}(p=0.06$ ), respectively. The mean increase in CD4 at week 12 in NHL cases compared to controls was $13(n=5)$ vs. $74(n=50)(p=0.284)$. Mean VL $\log _{10}$ reduction in NHL cases versus controls at week 12 was $2.79(n=5)$ vs. $1.94(n=50)(p=0.045)$.

Conclusions: An unexpectedly high rate of NHL was detected among treatment-experienced patients achieving a high level of virologic response with newer-class antiretrovirals. We observed trends toward lower baseline CD4 and higher baseline VL in NHL cases, with a significantly greater decline in VL among cases by 12 weeks. HIVrelated NHL can occur in the setting of immune reconstitution. Potential immunologic, virologic, and newer-class antiretroviral-specific factors associated with rapid development of NHL warrants further investigation.
\end{abstract}

\section{Introduction}

Non-Hodgkin lymphoma (NHL) is an HIV-associated malignancy that has been decreasing in incidence, ranging from approximately 1 to 3 cases per 1,000 personyears, among HIV-infected persons in the highly active

\footnotetext{
* Correspondence: greghuhn@gmail.com

'Division of Infectious Diseases, The Ruth M. Rothstein CORE Center, 2020 W. Harrison St., Chicago, Illinois, 60612, USA

Full list of author information is available at the end of the article
}

antiretroviral therapy (HAART) era, representing a roughly10-fold reduction from the pre-HAART era [1-9]. The main determinants for increased risk of NHL in HIV-infected persons are prolonged immunosuppression with T-cell depletion and uncontrolled plasma HIV viremia [3,4,10-15]. Epstein-Barr virus (EBV) activation has been linked to B-cell stimulation in the most common types of HIV-related NHL, diffuse large cell nonHodgkin and Burkitt lymphomas $[10,16,17]$. Upon 
initiation of effective HAART in patients with severe immunodeficiency, immune restoration may be adversely affected by a dysregulation of pathogen-specific immune responses, commonly referred to as immune reconstitution inflammatory syndrome (IRIS) $[18,19]$. B-cell NHL as a manifestation of IRIS is poorly characterized and has rarely been reported; it has mainly been recognized as NHL recurrence in patients with a previous diagnosis of NHL [20-22].

During 2006 to 2008, an unprecedented number of new antiretrovirals became available through expanded access programs (EAP) for treatment-experienced HIVinfected patients with multiple-class drug resistance. We report cases of B-cell NHL among patients without prior history of NHL diagnosed rapidly after initiating newer class antiretrovirals during the EAP study period, and examine the immunologic and virologic factors associated with potential IRIS-mediated NHL.

\section{Methods}

Two affiliated HIV clinics in Chicago, IL participated in open-label EAP trials for etravirine (TMC125-C214), raltegravir (MK0518-023), and maraviroc (A4001050) during December 2006 to January 2008. Protocols were approved by the John H. Stroger Jr. Hospital of Cook County and Rush University Medical Center institutional review board (IRB), and all subjects provided written informed consent prior to enrollment to each EAP.

During the baseline visit, physical exam and review of systems (an inventory of systems-based symptoms) were performed and newer-class antiretrovirals were distributed with optimized background regimens. The last CD4 count and HIV RNA viral load (VL) measured in a subject before regimens including newer-class agents were initiated were considered baseline values. Subjects were evaluated for adverse events, CD4 and HIV RNA VL at weeks 4 ( \pm 1 week) and 12 ( \pm 2 weeks), and then every 12 weeks through 48 weeks as available.

We compared patients without NHL (controls) with those who developed NHL (cases) in a retrospective cohort study among subjects enrolled upon initiation of newer-class antiretrovirals. A NHL case was defined as a tissue diagnosis confirmed by pathologic examination and immunohistochemical staining in a patient without prior history of NHL, with symptoms recorded after starting newer-class regimens during the EAP study period. All NHL cases were reported as serious adverse events to the EAP sponsor. Differences in demographic information, including median age and sex, and baseline median values of CD4 and $\log _{10} \mathrm{VL}$, were calculated using a Mann Whitney test. Mean change in CD4 and $\log _{10}$ VL in NHL cases compared to controls at week 12, a time point at which values were collected among all cases, was analyzed using a 2 -sided $t$ test. The $\log _{10}$ of an undetectable HIV RNA VL ( $<75$ copies/ml) was set at 1.90 , and at 5.70 for a VL $>500,000$. Risk ratios and related p-values for NHL diagnoses associated with current antiretroviral use, including nucleos(t)ide reverse transcriptase inhibitor class, raltegravir, etravirine, maraviroc, darunavir/ritonavir, and enfuvirtide, were calculated using a Mantel-Haentzel $\chi^{2}$ test, or Fisher's exact test where appropriate. The $\alpha$ of statistical significance was $<0.05$. All analysis was performed using SPSS version 11.5 for Windows (SPSS Inc, Chicago, IL).

\section{Results}

There were 5 new NHL cases identified among 78 total subjects enrolled during the EAP study period (mean incidence $=64.1 / 1000$ patient-years) (Table 1$)$. Two of these patients with NHL were screened for the raltegravir protocol MK 0518-023, though received raltegravir after the protocol closed in October 2007 upon FDA licensure. The median duration from HIV diagnosis to onset of NHL illness was 16 years. The median age of both cases and controls was 46 years $(\mathrm{p}=1.0)$. Four of 5 cases were male (80\%) compared to males comprising $83 \%(\mathrm{n}=60)$ of controls $(\mathrm{p}=1.0)$. The median time from starting newer-class regimens to NHL symptom onset was 5 weeks.

At baseline, the median CD4 and VL for NHL cases $(\mathrm{n}=5)$ versus controls $(\mathrm{n}=73)$ were 44 vs.117 cells/ $\mathrm{mm} 3(\mathrm{p}=0.09)$ and 5.2 vs. $4.2 \log _{10}(\mathrm{p}=0.06)$, respectively. The mean increase in CD4 at week 12 in NHL cases compared to controls was $13(n=5)$ vs. $74(n=50)$ $(\mathrm{p}=0.284)$ (figure 1$)$. Mean VL $\log _{10}$ reduction in NHL cases versus controls at week 12 was $2.79(n=5)$ vs. 1.94 $(\mathrm{n}=50)(\mathrm{p}=0.045)$ (figure 2). At 12 weeks, 60\% $(\mathrm{n}=3)$ of cases had undetectable VL compared to $64 \%(n=47)$ of controls $(\mathrm{p}=1.0)$, although the VL for patient 4 was nearly undetectable by week 12 at 84 copies $/ \mathrm{ml}$.

All 5 NHL cases received raltegravir. One NHL case received etravirine and no cases received maraviroc. There were no statistically significant associations between receipt of specific antiretrovirals and new NHL diagnosis (Table 2).

\section{Discussion}

An unexpectedly high incidence of NHL, greater than 20fold higher than currently observed in large cohort registries, was detected among treatment-experienced patients with HIV achieving high levels of virologic response with newer-class antiretrovirals. Before initiation of new HAART regimens, we observed a trend toward lower baseline CD4 cell counts and higher VLs in NHL cases, suggesting a higher degree of immunosuppression in these patients than in patients without NHL. Virologic response to newer-class HAART regimens was significantly greater at 12 weeks among all NHL cases, with a majority of these 
Table 1 Clinical, immunologic, and virologic characteristics among subjects diagnosed with NHL after starting newerclass antiretroviral regimens

\begin{tabular}{|c|c|c|c|c|c|}
\hline & Patient 1 & Patient 2 & Patient 3 & Patient 4 & Patient 5 \\
\hline Age (years) & 46 & 57 & 47 & 46 & 43 \\
\hline Sex & Male & Male & Male & Male & Female \\
\hline Race/Ethnicity & Black & Black & Black & Hispanic, non-Black & Black \\
\hline $\begin{array}{l}\text { Hepatitis B or } \\
\text { hepatitis C } \\
\text { coinfection }\end{array}$ & No & No & No & No & No \\
\hline $\begin{array}{l}\text { Year of HIV } \\
\text { diagnosis }\end{array}$ & 1996 & 1983 & 1988 & 1991 & 2002 \\
\hline $\begin{array}{l}\text { Antiretroviral } \\
\text { regimen before } \\
\text { starting newer- } \\
\text { class HAART }\end{array}$ & $\begin{array}{l}\text { Tenofovir/ } \\
\text { emtricitabine, } \\
\text { lopinavir/ritonavir }\end{array}$ & $\begin{array}{l}\text { Tenofovir, } \\
\text { lamivudine, } \\
\text { lopinavir/ritonavir }\end{array}$ & $\begin{array}{l}\text { Tenofovir/emtricitabine, } \\
\text { zidovudine }\end{array}$ & $\begin{array}{l}\text { Emtricitabine, nevirapine, } \\
\text { saquinavir, ritonavir }\end{array}$ & $\begin{array}{l}\text { Zidovudine/lamivudine, } \\
\text { efavirenz }\end{array}$ \\
\hline $\begin{array}{l}\text { Newer-class } \\
\text { HAART } \\
\text { Regimens }\end{array}$ & $\begin{array}{l}\text { Raltegravir, darunavir, } \\
\text { ritonavir, enfurvitide }\end{array}$ & $\begin{array}{l}\text { Raltegravir, } \\
\text { tenofovir/ } \\
\text { emtricitabine, } \\
\text { darunavir, ritonavir }\end{array}$ & $\begin{array}{l}\text { Raltegravir, etravirine, } \\
\text { tenofovir/emtricitabine, } \\
\text { zidovudine }\end{array}$ & $\begin{array}{l}\text { Raltegravir, tenofovir/ } \\
\text { emtricitabine, zidovudine, } \\
\text { darunavir, ritonavir }\end{array}$ & $\begin{array}{l}\text { Raltegravir, tenofovir/ } \\
\text { emtricitabine, darunavir, } \\
\text { ritonavir }\end{array}$ \\
\hline $\begin{array}{l}\text { Date of newer- } \\
\text { class HAART } \\
\text { initiation }\end{array}$ & June 2007 & November 2007 & July 2007 & October 2007 & December 2007 \\
\hline $\begin{array}{l}\text { Interval } \\
\text { between } \\
\text { newer- class } \\
\text { HAART } \\
\text { initiation and } \\
\text { symptom } \\
\text { onset (weeks) }\end{array}$ & 3.5 & 3 & 20 & 6 & 5 \\
\hline $\begin{array}{l}\text { Symptoms at } \\
\text { onset of NHL }\end{array}$ & $\begin{array}{l}\text { Ataxia, urinary } \\
\text { incontinence }\end{array}$ & $\begin{array}{l}\text { Left upper } \\
\text { extremity } \\
\text { numbness and } \\
\text { weakness, diplopia }\end{array}$ & Left neck mass & Low back pain, weight loss & Odonophagia, fever \\
\hline Baseline CD4 & 6 & 128 & 44 & 69 & 27 \\
\hline $\begin{array}{l}\text { Week } 4( \pm 1) \\
\text { CD4 }\end{array}$ & Not performed & Not performed & 234 & 195 & Not performed \\
\hline $\begin{array}{l}\text { Week } 12( \pm 2) \\
\text { CD4 }\end{array}$ & 15 & 4 & 250 & 40 & 33 \\
\hline $\begin{array}{l}\text { Week } 24( \pm 2) \\
\text { CD4 }\end{array}$ & Not performed & 112 & 294 & Not performed (deceased) & Not performed \\
\hline $\begin{array}{l}\text { Baseline HIV } \\
\text { viral load }\end{array}$ & $1,135,366$ & 8,111 & $>500,000$ & 156,303 & 17,767 \\
\hline $\begin{array}{l}\text { Week } 4( \pm 1) \\
\text { viral load }\end{array}$ & Not performed & Not performed & 132 & 84 & Not performed \\
\hline $\begin{array}{l}\text { Week } 12( \pm 2) \\
\text { viral load }\end{array}$ & 1,356 & Undetectable & Undetectable & 195 & Undetectable \\
\hline $\begin{array}{l}\text { Week } 24( \pm 2) \\
\text { viral load }\end{array}$ & Not performed & Undetectable & Undetectable & Not performed (deceased) & Not performed \\
\hline $\begin{array}{l}\text { Imaging } \\
\text { findings }\end{array}$ & $\begin{array}{l}\text { Brain MRI: } 2.5 \mathrm{~cm} \\
\text { necrotic rim- } \\
\text { enhancing lesion in } \\
\text { the right basal } \\
\text { ganglia with } \\
\text { extensive vasogenic } \\
\text { edema }\end{array}$ & $\begin{array}{l}\text { Brain MRI: two } \\
\text { enhancing } \\
\text { cavernous lesions } \\
\text { abutting the right } \\
\text { and left internal } \\
\text { carotid arteries }\end{array}$ & $\begin{array}{l}\text { Neck CT scan: multiple } \\
\text { enlarged left-sided level II to } \\
\text { V lymph nodes with central } \\
\text { necrosis and peripheral } \\
\text { enhancement, } \\
\text { lymphadenopathy in the left } \\
\text { supraclavicular region }\end{array}$ & $\begin{array}{l}\text { Chest/abdominal/pelvic CT } \\
\text { scan: massive } \\
\text { lymphadenopathy in the } \\
\text { neck, left supraclavicular and } \\
\text { paratracheal regions, bilateral } \\
\text { hilum, retroperitoneum, } \\
\text { paraaortic, peripancreatic, } \\
\text { and retrograstric regions, } \\
\text { extending into the splenic } \\
\text { hilum and left kidney, with } \\
\text { bilateral renal vessels } \\
\text { displaced anteriorly. Multiple } \\
\text { masslike bilateral pulmonary } \\
\text { nodules }\end{array}$ & $\begin{array}{l}\text { Neck CT scan: bilateral } \\
\text { level II } \\
\text { lymphadenopathy and a } \\
6 \mathrm{~mm} \text { nodule in the left } \\
\text { apex with mild } \\
\text { surrounding } \\
\text { inflammation }\end{array}$ \\
\hline
\end{tabular}


Table 1 Clinical, immunologic, and virologic characteristics among subjects diagnosed with NHL after starting newerclass antiretroviral regimens (Continued)

\begin{tabular}{|c|c|c|c|c|c|}
\hline $\begin{array}{l}\text { Biopsy site and } \\
\text { specimen }\end{array}$ & $\begin{array}{l}\text { Right medial } \\
\text { temporal brain } \\
\text { biopsy }\end{array}$ & $\begin{array}{l}\text { Left axilla lymph } \\
\text { node excisional } \\
\text { biopsy }\end{array}$ & $\begin{array}{l}\text { Left cervical lymph node } \\
\text { excisional biopsy }\end{array}$ & $\begin{array}{l}\text { Left neck lymph node fine } \\
\text { needle aspirate }\end{array}$ & $\begin{array}{l}\text { Right lateral } \\
\text { oropharyngeal wall } \\
\text { biopsy via larynoscopy }\end{array}$ \\
\hline Pathology & $\begin{array}{l}\text { Diffuse large B-cell } \\
\text { lymphoma }\end{array}$ & $\begin{array}{l}\text { Atypical Burkitt } \\
\text { lymphoma with } \\
\text { translocation }(8,14)\end{array}$ & Diffuse large B-cell lymphoma & $\begin{array}{l}\text { Diffuse large B-cell } \\
\text { lymphoma }\end{array}$ & $\begin{array}{l}\text { Plasmablastic large B- } \\
\text { cell lymphoma }\end{array}$ \\
\hline $\begin{array}{l}\text { EBV in situ } \\
\text { hybridization }\end{array}$ & Positive & Positive & $\begin{array}{l}\text { Tissue preparation } \\
\text { inadequate }\end{array}$ & Not performed & Positive \\
\hline Chemotherapy & Yes & Yes & Yes & Yes & Yes \\
\hline Outcome & Died August 2008 & Survived & Survived & Died March 2008 & Survived \\
\hline
\end{tabular}

patients achieving viral suppression with undetectable VL, compared to patients without NHL. A striking characteristic in NHL cases was the rapid onset of symptomatic disease which occurred at a median of 5 weeks after starting new HAART regimens. Our analysis suggests that the development of NHL may be attributable to either severe immunosuppression in these patients or complications from IRIS.

The degree of immunosuppression in HIV infection has long been linked with risk of developing NHL $[7,23,24]$. In early reports assessing immunologic and virologic parameters associated with NHL, nadir CD4 count or low time-weighted mean CD4 count appeared to correlate with a high risk of NHL, which would support hypotheses that a long-term immunocompromised state may promote emergence of NHL $[3,25]$. Contemporary studies, however, have demonstrated that cumulative HIV viremia, particularly recent exposure to viremia, and the latest CD4 count measured before the onset of symptomatic NHL may be the most HIV-specific predictive factors for NHL oncogenesis [11,12,14,15,24,26,27]. Our analysis correlates with prior studies documenting low CD4 counts in patients with virologic failure immediately before the onset of NHL.

An important feature of our cohort was the finding of symptomatic NHL occurring in the setting of profound

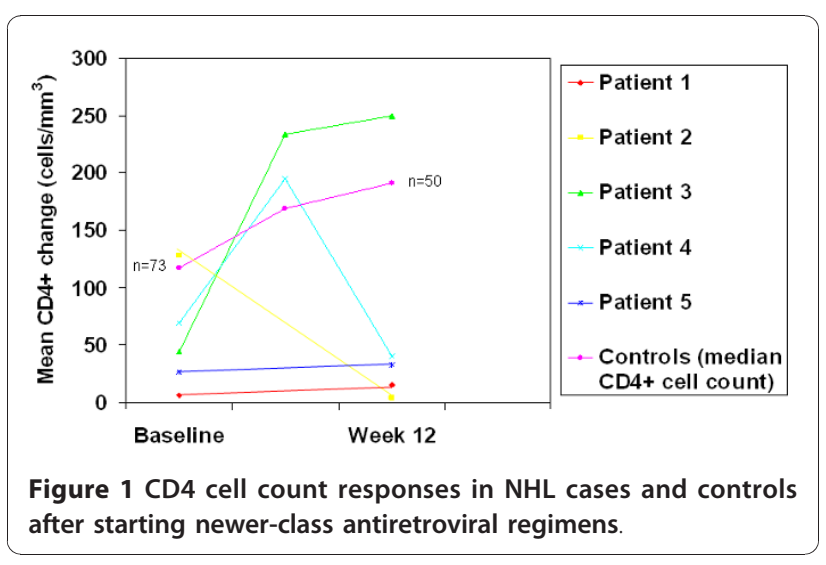

HIV viral load decline following initiation of HAART. This phenomenon raises the question of whether the degree and velocity of virologic response we can now achieve due to the simultaneous availability of new agents or possible unique properties of newer-class antiretrovirals may have facilitated an abnormal lymphoproliferative pathway. Clinically, in the largest cohort study of IRIS among 180 patients, the intensity of the viral load decrease within 90 days of starting HAART in antiretroviral naïve patients was the primary factor in developing IRIS. A significant association between CD4 cell count increase and IRIS was not seen until after 3 months to 9 months of HAART initiation [28]. The immunopathology of IRIS is believed to be largely mediated by a provoking antigen. In conditions in which inflammatory cell infiltration and cellular proliferation of affected tissues occur, pathogen-specific CD8 T cell responses and enhanced cytokine production appear to predominate [29-32]. In our study, EBV was identified in all NHL cases with adequate tissue for pathology

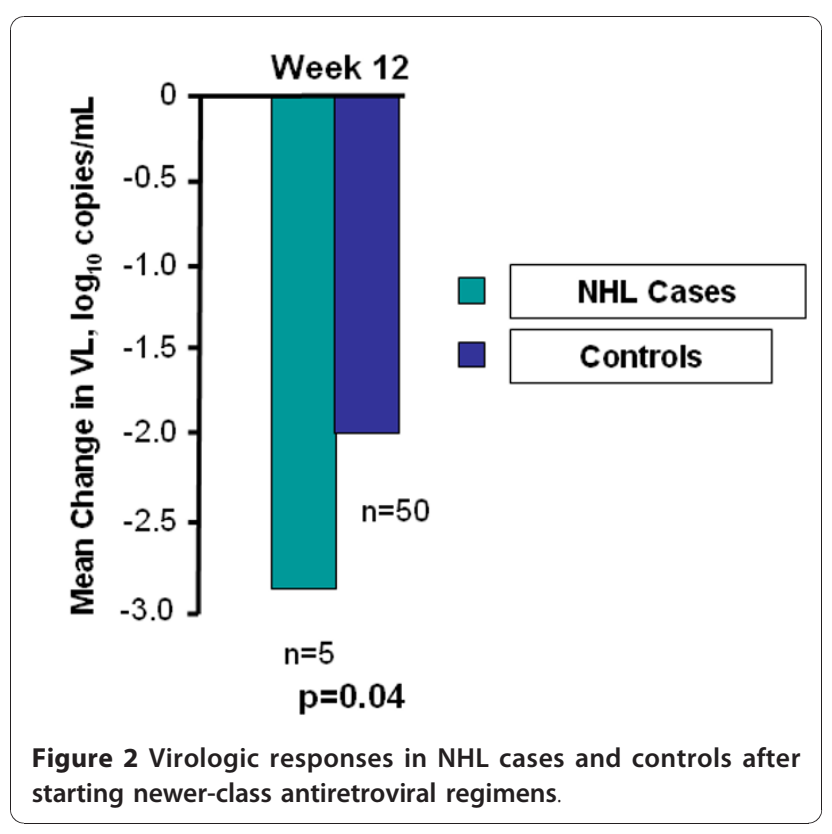


Table 2 Antiretroviral use and risk ratios for development of $\mathrm{NHL}$ in subjects after starting newerclass antiretroviral regimens

\begin{tabular}{lllll}
\hline Antiretroviral & $\begin{array}{l}\mathbf{N H L} \text { cases } \\
(\mathbf{n}=\mathbf{5})\end{array}$ & $\begin{array}{l}\text { Controls } \\
(\mathbf{n}=\mathbf{7 3})\end{array}$ & $\begin{array}{l}\text { Unadjusted } \\
\text { Odds Ratio }\end{array}$ & $\mathbf{9 5 \%} \mathbf{C l}$ \\
\hline $\begin{array}{l}\text { Nucleos(t)ide } \\
\text { reverse } \\
\text { transcriptase } \\
\text { inhibitors }\end{array}$ & $100 \%$ & $97 \%$ & $\mathrm{NC}$ & $(\mathrm{p}=1.0)$ \\
$\begin{array}{l}\text { Raltegravir } \\
\text { Etravirine }\end{array}$ & $100 \%$ & $86 \%$ & $\mathrm{NC}$ & $(\mathrm{p}=1.0)$ \\
Maraviroc & $20 \%$ & $53 \%$ & 0.29 & $0.02-2.0$ \\
Darunavir/ritonavir & $80 \%$ & $11 \%$ & 0 & \\
Enfuvirtide & $20 \%$ & $49 \%$ & 2.8 & $0.30-26.6$ \\
\hline
\end{tabular}

NC: not calculated

examination. Control of EBV-infected B cells is achieved primarily by CD8 $\mathrm{T}$ cells $[33,34]$. Loss of EBV-specific CD8 $\mathrm{T}$ cell function has been associated with a decrease in total CD4 T cells in HIV-positive patients with EBVrelated NHL, suggesting a lack of EBV-specific CD4 T cell help could accelerate NHL disease progression [35-41]. Loss of CD4 and CD8 memory T cells directed against latent EBV antigen (EBV nuclear antigen 1) in patients with poorly controlled HIV infection may be important components in progression to EBV-related NHL. In the Amsterdam Cohort, latent EBV-specific $\mathrm{CD} 4$ and $\mathrm{CD} 8 \mathrm{~T}$ cell responses were reestablished, without changes in the EBV viral load, when effective HAART was taken longitudinally over a median of five years [42]. HIV-related NHL is characterized by highgrade tumor growth, and in recent multicenter cohort analyses incident malignancy has been assigned at $\geq 30$ days from initiation of HAART [26]. In patients with low CD4+ counts and HIV viremia, which may promote EBV-infected B cell clonal expansion, the evolution toward EBV-related NHL may be too advanced to be modified by EBV-specific cytolytic T cell recovery upon the initiation of effective HAART. Alternatively, during an interval with rapid HIV viral decay, as can occur upon introduction of newer-class antiretroviral regimens, aberrant EBV-specific CD4, CD8, and cytokine IRIS responses may impact memory B cell stimulation, which may produce a greater risk for NHL emergence.

There were no distinct antiretrovirals that achieved statistical significance as a risk factor for developing NHL in our cohort, although the high rate of receipt of nucleos $(\mathrm{t})$ ide agents and raltegravir in both groups may preclude useful comparisons. Raltegravir, however, was the only antiretroviral taken universally by all patients with NHL as part of their new HAART regimen. In the licensing trials for raltegravir in treatment-experienced patients, a disproportionately higher rate of malignancy had been reported. NHL was the most common HIV-related malignancy in these studies [43]. HIV-1 integrase inhibitors specifically inhibit the viral enzyme integrase that catalyzes strand transfer insertion of proviral DNA into the host-cell genome [44,45]. HIV-1 integrase inhibitors have a mechanism of action similar to recombinationactivating genes 1 and 2 (RAG1/2), a recombinase complex fundamental to $\mathrm{V}(\mathrm{D}) \mathrm{J}$ recombination in the assemblage of human immunoglobulins, both heavy and light chains, and $\mathrm{T}$ cell receptors, ultimately leading to $\mathrm{B}$ and $T$ cell maturation [46-50]. In vitro studies have shown HIV-1 integrase inhibitors can interfere with human DNA cleavage and disintegration activities of RAG1/2 [51]. Infrequently, RAG $1 / 2$ has been shown to recognize and bind mistakenly to cryptic DNA sequences that are unrelated to $\mathrm{V}(\mathrm{D}) \mathrm{J}$ recombination, and these DNA elements may play a significant role in the development of lymphoid tumors [52]. RAG1/2 chromosomal transposition has also been documented in human $\mathrm{T}$ cells, though it appears to be an uncommon event [53]. Despite its rarity, certain oncogenic chromosomal translocations which can juxtapose immunoglobulin and $\mathrm{T}$ cell receptor enhancers with proto-oncogenes may be the result of RAG1/2 mediated transposition [54]. In cases suggestive of IRIS-mediated neoplasm in patients taking an integrase inhibitor as part of their HAART regimen, it is possible that any potential perturbations to the RAG1/ 2 system, coupled with dysfunctional $\mathrm{T}$ cells or enhanced cytokine responses, may be associated with the development of symptomatic malignancy.

Our study had several limitations. The analysis was prompted by reported adverse events during the EAP time period, therefore because of the nonrandomized, observational nature of the cohort, we may not have accounted for other significant risk factors for newly recognized NHL beyond HIV immunological and virologic baseline features and response rates to antiretroviral agents. NHL may have been present before patients started the newer-class HAART regimens, though physical exams and a review of systems that were obtained on all subjects upon distribution of their new antiretroviral therapy did not uncover symptomatic disease in any of the patients. At the median time of NHL symptom onset (5 weeks) after initiation of new HAART regimens, evaluable CD4 count and viral loads were either not obtained or lower due to chemotherapy for meaningful analysis in 3 of $5 \mathrm{NHL}$ cases (Patients 1, 2, and 4); therefore, the implication that an IRIS possibly contributed to the early diagnosis of these malignancies is inferred primarily upon the virologic response kinetics in all cases by week 12 . EBV was not identified in 2 of the 5 patients, though in both of these cases alternative pathogens were not isolated and sample limitations of the diagnostic tissue precluded evaluation for EBV markers. Lastly, the 
small sample size of the cohort may have led to less precision in the risk factor analysis.

In view of our results, clinicians should be vigilant in monitoring highly treatment-experienced patients for signs and symptoms of NHL as a potential IRIS complication shortly after starting potent antiretroviral therapy. Measuring elevations in circulating free immunoglobulin light chains in serum may be a sensitive marker for predicting NHL in HIV-infected patients, which may be a useful screening tool in patients at increased risk for NHL [55]. Given the similar activity of HIV integrase inhibitors to the RAG1/2 system, which is critical to B and $\mathrm{T}$ cell maturation, HAART regimens containing integrase inhibitors merit particular attention and further investigation as a potential novel mechanism in the development of possible IRIS-related NHL in patients with depressed immunity.

\section{List of Abbreviations}

(NHL): non-Hodgkin lymphoma; (HAART): highly active antiretroviral therapy; (EBV): Epstein-Barr virus; (IRIS): immune reconstitution inflammatory syndrome; (EAP): expanded access programs; (IRB): institutional review board; $(\mathrm{VL})$ : viral load;

\section{Acknowledgements and Funding}

We wish to thank Kathy McLoyd, Rebecca Goldberg, Hamid Bouiri, and Mieoak Bahk from The Ruth M. Rothstein CORE Center for their dedication in the management of these patients, and to thank the patients themselves for their participation in these expanded access programs.

Grant support was provided by Pfizer and Tibotec for data collection under their EAP protocols. The EAP sponsors were not involved in the study design, analysis, and interpretation of data, the writing of the report, or the decision to submit the paper for publication.

\section{Author details}

'Division of Infectious Diseases, The Ruth M. Rothstein CORE Center, 2020 W. Harrison St., Chicago, Illinois, 60612, USA. ²Department of Medicine, Rush University Medical Center, 600 S. Paulina St., Chicago, Illinois, 60612, USA. ${ }^{3}$ Department of Pharmacy Practice, University of Illinois at Chicago, 833 South Wood St., Illinois, 60612, USA. ${ }^{4}$ Department of Pharmacy, The Ruth M. Rothstein CORE Center, 2020 W. Harrison St., Chicago, Illinois, 60612, USA.

\section{Authors' contributions}

GDH participated in the study concept and design, had full access to all of the data, carried out acquisition, analysis, and interpretation of the data, drafted the manuscript, supervised the study, and takes responsibility for the integrity of the data and the accuracy of the data analysis. SM participated in the study concept and design, carried out acquisition, analysis, and interpretation of the data, and provided administrative, technical or material support for the study. SV carried out acquisition of the data, and provided administrative, technical or material support for the study. FT carried out acquisition of the data and provided administrative, technical or material support for the study. CC carried out acquisition of the data and provided administrative, technical or material support for the study. RL carried out acquisition, analysis, and interpretation of the data, submitted critical revisions of the manuscript for important intellectual content, and provided administrative, technical or material support for the study. BM participated in the study concept and design, carried out acquisition of the data, submitted critical revisions of the manuscript for important intellectual content, and provided administrative, technical or material support for the study. DS carried out acquisition of the data and submitted critical revisions of the manuscript for important intellectual content. BS carried out acquisition of the data and submitted critical revisions of the manuscript for important intellectual content. OA carried out acquisition of the data. PH carried out acquisition of the data. AT participated in the study concept and design, carried out acquisition of the data, submitted critical revisions of the manuscript for important intellectual content, and provided administrative, technical or material support for the study. HK participated in the study concept and design, carried out analysis and interpretation of the data, submitted critical revisions of the manuscript for important intellectual content, supervised the study, and provided administrative, technical or material support for the study. DB participated in the study concept and design, carried out acquisition of the data, submitted critical revisions of the manuscript for important intellectual content, supervised the study, and provided administrative, technical or material support for the study. All authors read and approved the final manuscript.

\section{Author Competing Interests}

The following authors have acknowledged competing interests: GDH has served as a consultant for Gilead, Medlmmune, and Genentech, received grant support from Gilead, GlaxoSmithKline, Vertex, and Merck, and received honoraria from Gilead, GlaxoSmithKline, Genentech, Merck, Sanofi Pasteur, Tibotec, Novartis, and Viiv. RH has served as a consultant and received honoraria from Gilead, and received grant support from Gilead and Tibotec. BM holds stock/stock options in GlaxoSmithKline and Pfizer, and his wife is employed by Viiv. BS has received grant support from Schering Plough and Abbott. OA has received grant support from Merck and honoraria from Abbott. AT has served as a consultant for Tibotec and received grant support from Abbott. HK has served as a consultant for Tibotec and Virco, received honoraria from Bristol-Myers Squibb, GlaxoSmithKline, and Tibotec, and holds stock in Abbott, GlaxoSmithKline, and Merck. DB has served as a consultant for Tibotec and Virco, received grant support from Merck and Pfizer, Gilead, GlaxoSmithKline, payment for development of educational presentations for Gilead. All other authors have no competing interests.

Received: 13 October 2010 Accepted: 14 December 2010

Published: 14 December 2010

\section{References}

1. Patel P, Hanson DL, Sullivan PS, Novak RM, Moorman AC, Tong TC, Holmberg SD, Brooks JT: Incidence of types of cancer among HIVinfected persons compared with the general population in the United States, 1992-2003. Ann Intern Med 2008, 148:728-736.

2. Bonnet F, Balestre E, Thiebaut R, Morlat P, Pellegrin JL, Neau D, Dabis F: Factors associated with the occurrence of AIDS-related non-Hodgkin lymphoma in the era of highly active antiretroviral therapy: Aquitaine Cohort, France. Clin Infect Dis 2006, 42:411-417.

3. Matthews GV, Bower M, Mandalia S, Powles T, Nelson MR, Gazzard BG: Changes in acquired immunodeficiency syndrome-related lymphoma since the introduction of highly active antiretroviral therapy. Blood 2000, 96:2730-2734.

4. Kirk O, Pedersen C, Cozzi-Lepri A, Antunes F, Miller V, Gatell JM, Katlama C, Lazzarin A, Skinhoj P, Barton SE: Non-Hodgkin lymphoma in HIV-infected patients in the era of highly active antiretroviral therapy. Blood 2001, 98:3406-3412.

5. Crum-Cianflone N, Hullsiek KH, Marconi V, Weintrob A, Ganesan A, Barthel RV, Fraser S, Agan BK, Wegner S: Trends in the incidence of cancers among HIV-infected persons and the impact of antiretroviral therapy: a 20-year cohort study. AIDS 2009, 23:41-50.

6. Besson C, Goubar A, Gabarre J, Rozenbaum W, Pialoux G, Chatelet FP, Katlama C, Charlotte F, Dupont B, Brousse N, et al: Changes in AIDS-related lymphoma since the era of highly active antiretroviral therapy. Blood 2001, 98:2339-2344.

7. Polesel J, Clifford GM, Rickenbach M, Dal Maso L, Battegay M, Bouchardy C, Furrer H, Hasse B, Levi F, Probst-Hensch NM, et al: Non-Hodgkin lymphoma incidence in the Swiss HIV Cohort Study before and after highly active antiretroviral therapy. AIDS 2008, 22:301-306.

8. Dal Maso L, Franceschi S: Epidemiology of non-Hodgkin lymphomas and other haemolymphopoietic neoplasms in people with AIDS. Lancet Oncol 2003, 4:110-119.

9. Cote TR, Biggar RJ, Rosenberg PS, Devesa SS, Percy C, Yellin FJ, Lemp G, Hardy C, Geodert JJ, Blattner WA: Non-Hodgkin's lymphoma among people with AIDS: incidence, presentation and public health burden. AIDS/Cancer Study Group. Int J Cancer 1997, 73:645-650.

10. Grulich AE, Wan X, Law MG, Milliken ST, Lewis CR, Garsia RJ, Gold J, Finlayson RJ, Cooper DA, Kaldor JM: B-cell stimulation and prolonged 
immune deficiency are risk factors for non-Hodgkin's lymphoma in people with AIDS. AIDS 2000, 14:133-140.

11. Bruyand M, Thiebaut R, Lawson-Ayayi S, Joly P, Sasco AJ, Mercie P, Pellegrin JL, Neau D, Dabis F, Morlat P, et al: Role of uncontrolled HIV RNA level and immunodeficiency in the occurrence of malignancy in HIVinfected patients during the combination antiretroviral therapy era: Agence Nationale de Recherche sur le Sida (ANRS) CO3 Aquitaine Cohort. Clin Infect Dis 2009, 49:1109-1116.

12. Bower M, Fisher M, Hill T, Reeves I, Walsh J, Orkin C, Phillips AN, Bansi L, Gilson R, Easterbrook P, et al: CD4 counts and the risk of systemic nonHodgkin's lymphoma in individuals with HIV in the UK. Haematologica 2009, 94:875-880.

13. Zoufaly ASH-J, An Der Heiden M, Kollan C, Hoffmann C, van Lunzen J, et al: Risk Factors for HIV-associated Hodgkin's Lymphoma during HAART in a Large Observational Study. 16th Conference on Retroviruses and Opportunistic Infections Montreal, Canada; 2009, Abstract 868.

14. Guiguet M, Boue F, Cadranel J, Lang JM, Rosenthal E, Costagliola D: Effect of immunodeficiency, HIV viral load, and antiretroviral therapy on the risk of individual malignancies (FHDH-ANRS CO4): a prospective cohort study. Lancet Oncol 2009, 10:1152-1159.

15. Engels EA, Pfeiffer RM, Landgren O, Moore RD: Immunologic and virologic predictors of AIDS-related non-hodgkin lymphoma in the highly active antiretroviral therapy era. J Acquir Immune Defic Syndr 2010, 54:78-84.

16. Grogg KL, Miller RF, Dogan A: HIV infection and lymphoma. J Clin Pathol 2007, 60:1365-1372.

17. Tsibris AM, Paredes R, Chadburn A, Su Z, Henrich TJ, Krambrink A, Hughes MD, Aberg JA, Currier JS, Tashima K, et al: Lymphoma diagnosis and plasma Epstein-Barr virus load during vicriviroc therapy: results of the AIDS Clinical Trials Group A5211. Clin Infect Dis 2009, 48:642-649.

18. French MA: Disorders of immune reconstitution in patients with HIV infection responding to antiretroviral therapy. Curr HIV/AIDS Rep 2007, 4:16-21.

19. Shelburne SA, Hamill RJ, Rodriguez-Barradas MC, Greenberg SB, Atmar RL, Musher DW, Gathe JC Jr, Visnegarwala F, Trautner BW: Immune reconstitution inflammatory syndrome: emergence of a unique syndrome during highly active antiretroviral therapy. Medicine (Baltimore) 2002, 81:213-227.

20. Powles T, Thirlwell C, Nelson M, Bower M: Immune reconstitution inflammatory syndrome mimicking relapse of AIDS related lymphoma in patients with HIV 1 infection. Leuk Lymphoma 2003, 44:1417-1419.

21. Manabe YC, Campbell JD, Sydnor E, Moore RD: Immune reconstitution inflammatory syndrome: risk factors and treatment implications. J Acquir Immune Defic Syndr 2007, 46:456-462.

22. Knysz B, Kuliszkiewicz-Janus M, Jelen M, Podlasin R, Gladysz A: Non-Hodgkin's lymphoma as a rare manifestation of immune reconstitution disease in HIV-1 positive patients. Postepy Hig Med Dosw (Online) 2006, 60:547-551.

23. Grulich $A E$, van Leeuwen MT, Falster MO, Vajdic CM: Incidence of cancers in people with HIV/AIDS compared with immunosuppressed transplant recipients: a meta-analysis. Lancet 2007, 370:59-67.

24. Bhaskaran K, Brettle R, Porter K, Walker AS: Systemic non-Hodgkin lymphoma in individuals with known dates of HIV seroconversion: incidence and predictors. AIDS 2004, 18:673-681.

25. Stebbing J, Gazzard B, Mandalia S, Teague A, Waterston A, Marvin V, Nelson M, Bower M: Antiretroviral treatment regimens and immune parameters in the prevention of systemic AIDS-related non-Hodgkin's lymphoma. J Clin Oncol 2004, 22:2177-2183.

26. Zoufaly A, Stellbrink HJ, Heiden MA, Kollan C, Hoffmann C, van Lunzen J, Hamouda O: Cumulative HIV viremia during highly active antiretroviral therapy is a strong predictor of AIDS-related lymphoma. J Infect Dis 2009, 200:79-87.

27. Monforte A, Abrams D, Pradier C, Weber R, Reiss P, Bonnet F, Kirk O, Law M, De Wit S, Friis-Moller N, et al: HIV-induced immunodeficiency and mortality from AIDS-defining and non-AIDS-defining malignancies. AIDS 2008, 22:2143-2153.

28. Shelburne SA, Visnegarwala F, Darcourt J, Graviss EA, Giordano TP, White AC $\mathrm{Jr}$, Hamill RJ: Incidence and risk factors for immune reconstitution inflammatory syndrome during highly active antiretroviral therapy. AIDS 2005, 19:399-406.

29. Miller RF, Isaacson PG, Hall-Craggs M, Lucas S, Gray F, Scaravilli F, An SF: Cerebral CD8+ lymphocytosis in HIV-1 infected patients with immune restoration induced by HAART. Acta Neuropathol 2004, 108:17-23.
30. Gray F, Bazille C, Adle-Biassette H, Mikol J, Moulignier A, Scaravilli F: Central nervous system immune reconstitution disease in acquired immunodeficiency syndrome patients receiving highly active antiretroviral treatment. J Neurovirol 2005, 11(Suppl 3):16-22.

31. Mutimer HP, Akatsuka Y, Manley T, Chuang EL, Boeckh M, Harrington R, Jones T, Riddell SR: Association between immune recovery uveitis and a diverse intraocular cytomegalovirus-specific cytotoxic T cell response. J Infect Dis 2002, 186:701-705.

32. Tamburini J, Grimaldi D, Chiche JD, Bricaire F, Bossi P: Cytokine pattern in Kaposi's sarcoma associated with immune restoration disease in HIV and tuberculosis co-infected patients. AIDS 2007, 21:1980-1983.

33. Harty JT, Tvinnereim AR, White DW: CD8+ T cell effector mechanisms in resistance to infection. Annu Rev Immunol 2000, 18:275-308.

34. Rickinson $A B$, Moss DJ: Human cytotoxic T lymphocyte responses to Epstein-Barr virus infection. Annu Rev Immunol 1997, 15:405-431.

35. van Baarle D, Hovenkamp E, Callan MF, Wolthers KC, Kostense S, Tan LC Niesters HG, Osterhaus AD, McMichael AJ, van Oers MH, Miedema F: Dysfunctional Epstein-Barr virus (EBV)-specific CD8(+) T lymphocytes and increased EBV load in HIV-1 infected individuals progressing to AIDSrelated non-Hodgkin lymphoma. Blood 2001, 98:146-155.

36. Day CL, Lauer GM, Robbins GK, McGovern B, Wurcel AG, Gandhi RT, Chung RT, Walker BD: Broad specificity of virus-specific CD4+ T-helpercell responses in resolved hepatitis C virus infection. J Virol 2002, 76:12584-12595.

37. Rosenberg ES, Billingsley JM, Caliendo AM, Boswell SL, Sax PE, Kalams SA, Walker BD: Vigorous HIV-1-specific CD4+ T cell responses associated with control of viremia. Science 1997, 278:1447-1450.

38. McNeil AC, Shupert WL, lyasere CA, Hallahan CW, Mican JA, Davey RT Jr, Connors M: High-level HIV-1 viremia suppresses viral antigen-specific CD4(+) T cell proliferation. Proc Natl Acad Sci USA 2001, 98:13878-13883.

39. Gamadia LE, Remmerswaal EB, Weel JF, Bemelman F, van Lier RA, Ten Berge IJ: Primary immune responses to human CMV: a critical role for IFN-gamma-producing CD4+ T cells in protection against CMV disease. Blood 2003, 101:2686-2692

40. Walter EA, Greenberg PD, Gilbert MJ, Finch RJ, Watanabe KS, Thomas ED, Riddell SR: Reconstitution of cellular immunity against cytomegalovirus in recipients of allogeneic bone marrow by transfer of T-cell clones from the donor. N Engl J Med 1995, 333:1038-1044.

41. Gasser O, Bihl FK, Wolbers M, Loggi E, Steffen I, Hirsch HH, Gunthard HF, Walker BD, Brander C, Battegay M, Hess C: HIV patients developing primary CNS lymphoma lack EBV-specific CD4+ T cell function irrespective of absolute CD4+ T cell counts. PLoS Med 2007, 4:e96.

42. Piriou E, van Dort K, Nanlohy NM, van Oers MH, Miedema F, van Baarle D: Loss of EBNA1-specific memory CD4+ and CD8+ T cells in HIV-infected patients progressing to AIDS-related non-Hodgkin lymphoma. Blood 2005, 106:3166-3174.

43. Steigbigel RT, Cooper DA, Kumar PN, Eron JE, Schechter M, Markowitz M, Loutfy MR, Lennox JL, Gatell JM, Rockstroh JK, et al: Raltegravir with optimized background therapy for resistant HIV-1 infection. N Engl J Med 2008, 359:339-354

44. Savarino A: A historical sketch of the discovery and development of HIV1 integrase inhibitors. Expert Opin Investig Drugs 2006, 15:1507-1522.

45. Hare S, Gupta SS, Valkov E, Engelman A, Cherepanov P: Retroviral intasome assembly and inhibition of DNA strand transfer. Nature 11;464(7286):232-6.

46. Jones JM, Gellert $M$ : The taming of a transposon: $V(D) J$ recombination and the immune system. Immunol Rev 2004, 200:233-248.

47. Schatz DG: V(D)J recombination. Immunol Rev 2004, 200:5-11.

48. Schatz DG, Oettinger MA, Baltimore D: The V(D)J recombination activating gene, RAG-1. Cell 1989, 59:1035-1048.

49. Oettinger MA, Schatz DG, Gorka C, Baltimore D: RAG-1 and RAG-2, adjacent genes that synergistically activate $V(D) J$ recombination. Science 1990, 248:1517-1523.

50. Ramsden DA, Baetz K, Wu GE: Conservation of sequence in recombination signal sequence spacers. Nucleic Acids Res 1994, 22:1785-1796.

51. Melek M, Jones JM, O'Dea MH, Pais G, Burke TR Jr, Pommier $Y$, Neamati $N$, Gellert M: Effect of HIV integrase inhibitors on the RAG1/2 recombinase. Proc Natl Acad Sci USA 2002, 99:134-137.

52. Lewis SM, Agard E, Suh S, Czyzyk L: Cryptic signals and the fidelity of V(D) J joining. Mol Cell Biol 1997, 17:3125-3136. 
53. Messier TL, O'Neill JP, Hou SM, Nicklas JA, Finette BA: In vivo transposition mediated by V(D)J recombinase in human T lymphocytes. EMBO J 2003, 22:1381-1388.

54. Hiom K, Melek M, Gellert M: DNA transposition by the RAG1 and RAG2 proteins: a possible source of oncogenic translocations. Cell 1998, 94:463-470.

55. Landgren O, Goedert JJ, Rabkin CS, Wilson WH, Dunleavy K, Kyle RA, Katzmann JA, Rajkumar SV, Engels EA: Circulating serum free light chains as predictive markers of AIDS-related lymphoma. J Clin Oncol 2010, 28:773-779.

doi:10.1186/1742-6405-7-44

Cite this article as: Huhn et al.: Early development of non-hodgkin lymphoma following initiation of newer class antiretroviral therapy among HIV-infected patients - implications for immune reconstitution. AIDS Research and Therapy 2010 7:44.

\section{Submit your next manuscript to BioMed Central} and take full advantage of:

- Convenient online submission

- Thorough peer review

- No space constraints or color figure charges

- Immediate publication on acceptance

- Inclusion in PubMed, CAS, Scopus and Google Scholar

- Research which is freely available for redistribution

Submit your manuscript at www.biomedcentral.com/submit 